University of Michigan Law School

University of Michigan Law School Scholarship Repository

Law \& Economics Working Papers

3-14-2021

\title{
Tax Treaties, the Constitution, and the Noncompulsory Payment Rule
}

\author{
Reuven S. Avi-Yonah \\ University of Michigan Law School, aviyonah@umich.edu
}

Follow this and additional works at: https://repository.law.umich.edu/law_econ_current

Digipadrt of the Law and Economics Commons, Public Law and Legal Theory Commons, and the Tax Law Cemmens

Network

\section{Logo}

Working Paper Citation

Avi-Yonah, Reuven S., "Tax Treaties, the Constitution, and the Noncompulsory Payment Rule" (2021). Law \& Economics Working Papers. 178.

https://repository.law.umich.edu/law_econ_current/178

This Article is brought to you for free and open access by University of Michigan Law School Scholarship Repository. It has been accepted for inclusion in Law \& Economics Working Papers by an authorized administrator of University of Michigan Law School Scholarship Repository. For more information, please contact mlaw.repository@umich.edu. 
TAX TREATIES, THE CONSTITUTION, AND THE NONCOMPULSORY PAYMENT RULE

Reuven Avi-Yonah

\begin{abstract}
US Tax treaties have been regarded as self-executing since the first treaty (with France) was ratified in 1932. Rebecca Kysar has argued this raises a doubt on whether the treaties are constitutional, because tax treaties (like other treaties) are negotiated by the executive branch and ratified by the Senate with no involvement by the House, and all tax-raising measures must originate in the House under the Origination Clause (U.S. Const. Art I, section 7, clause 7). Her preferred solution is to make tax treaties non-self executing, but that would reverse the universal practice since 1932, and is therefore unlikely. Moreover, tax treaties are generally precluded from raising revenue by the Saving Clause (Art. 1(4)). But Kysar's argument raises another question in regard to the noncompulsory payment rule (Treas. Reg. 1.902-2(e)(5)). Under the noncompulsory payment rule, a US taxpayer who is entitled to a treaty benefit and does not avail itself of the benefit may not get a foreign tax credit for the excess of the withholding tax levied over the treaty rate (Treas. Reg. 1.902-2(e)(5), Example 6). But this means that the treaty raises the taxpayer's US taxes over the amount it would pay in the absence of a treaty, which in turn raises the constitutional issue invoked by Kysar. The paper concludes by questioning whether the noncompulsory payment rule is worth the complexity it imposes on both taxpayers and the IRS.
\end{abstract}


US Tax treaties have been regarded as self-executing since the first treaty (with France) was ratified in 1932. ${ }^{1}$ Rebecca Kysar has argued this raises a doubt on whether the treaties are constitutional, because tax treaties (like other treaties) are negotiated by the executive branch and ratified by the Senate with no involvement by the House, and all tax-raising measures must originate in the House under the Origination Clause (U.S. Const. Art I, section 7, clause 7). Her preferred solution is to make tax treaties non-self executing, i.e., to require them to be incorporated in legislation, as is the practice in many other countries (e.g., the UK). ${ }^{2}$

Kysar's solution would reverse the universal practice since 1932, and is therefore unlikely to be implemented. Moreover, tax treaties are generally precluded from affecting revenue from US taxpayers by the Saving Clause (Art. 1(4)). Under the Saving Clause, "this Convention shall not affect the taxation by a Contracting State of its residents (as determined under Article 4 (Resident)) and its citizens. " The Saving Clause is generally regarded as required by the Origination Clause because if a US tax treaty were to affect taxation of US citizens, this would violate the rule that all tax measures must originate in the House. ${ }^{3}$

But Kysar's argument raises another question in regard to the noncompulsory payment rule (Treas. Reg. 1.902-2(e)(5)). The noncompulsory payment rule, which has no statutory basis in the Code, states that:

An amount paid is not a compulsory payment, and thus is not an amount of tax paid, to the extent that the amount paid exceeds the amount of liability under foreign law for tax. An amount paid does not exceed the amount of such liability if the amount paid is determined by the taxpayer in a manner that is consistent with a reasonable interpretation and application of the substantive and procedural provisions of foreign law (including applicable tax treaties) in such a way as to reduce, over time, the taxpayer's reasonably expected liability under foreign law for tax, and if the taxpayer exhausts all effective and practical remedies, including invocation of

\footnotetext{
${ }^{1}$ US Treaties are self-executing if they do not require further Congressional action to implement once they are ratified by the Senate. See Foster v. Neilson, 27 U.S. 253, 254 (1829) (holding that a treaty governing Spanish land grants in Florida was not self-executing).

${ }^{2}$ Kysar, Rebecca M., On the Constitutionality of Tax Treaties (May 3, 2013). Yale Journal of International Law, Vol. 38, 2013, Brooklyn Law School, Legal Studies Paper No. 274, Available at SSRN: https://ssrn.com/abstract=2034904

${ }^{3}$ See, e.g., Technical Explanation of the US-UK Tax Treaty (2003): "Paragraph 2 also means that the Convention may not increase the tax burden on a resident of a Contracting State beyond the burden determined under domestic law. Thus, a right to tax given by the Convention cannot be exercised unless that right also exists under internal law. It follows that, under the principle of paragraph 2, a taxpayer's U.S. tax liability need not be determined under the Convention if the Code would produce a more favorable result." See also Jeffrey A. Schoenblum, Bilateral Transfer Tax Treaties, Tax Mgmt. Portfolios (BNA) No. 851 (2012) (noting that it is routinely accepted among tax professionals that, in order to comply with the Origination Clause, tax treaties cannot increase tax liability).
} 
competent authority procedures available under applicable tax treaties, to reduce, over time, the taxpayer's liability for foreign tax (including liability pursuant to a foreign tax audit adjustment). Where foreign tax law includes options or elections whereby a taxpayer's tax liability may be shifted, in whole or part, to a different year or years, the taxpayer's use or failure to use such options or elections does not result in a payment in excess of the taxpayer's liability for foreign tax. An interpretation or application of foreign law is not reasonable if there is actual notice or constructive notice (e.g., a published court decision) to the taxpayer that the interpretation or application is likely to be erroneous. In interpreting foreign tax law, a taxpayer may generally rely on advice obtained in good faith from competent foreign tax advisors to whom the taxpayer has disclosed the relevant facts. A remedy is effective and practical only if the cost thereof (including the risk of offsetting or additional tax liability) is reasonable in light of the amount at issue and the likelihood of success. A settlement by a taxpayer of two or more issues will be evaluated on an overall basis, not on an issue-by-issue basis, in determining whether an amount is a compulsory amount. A taxpayer is not required to alter its form of doing business, its business conduct, or the form of any business transaction in order to reduce its liability under foreign law for tax.

Two of the examples given in the regulation for noncompulsory payments do not involve tax treaties (Treas. Reg. 1.902-2(e)(5), Examples 1 and 5). Examples 2, 3 and 4 do involve a tax treaty that embodies the arm's length standard, but it is not clear that the existence vel non of the treaty affects the result, because the arm's length standard would usually apply to related party transactions under both US and foreign law in the absence of a treaty.

Similarly, most of the case law under the noncompulsory payment rule does not involve tax treaties, or if it does it only involves the arm's length standard, and the IRS has largely been unsuccessful in applying the rule to deny foreign tax credits. ${ }^{4}$ The exception is Procter \& Gamble, in which the taxpayer paid tax on the same royalties to both Korea and Japan, and was held to have violated the noncompulsory payments rule because it only tried to challenge the Korean tax under the applicable treaty but not the Japanese tax, so it could not get credit for the Japanese tax. ${ }^{5}$ But in this case as well, it is not clear that the treaty by itself changed the result.

However, the regulation also contains the following example:

\section{Example 6.}

The internal law of country $X$ imposes a 25 percent tax on the gross amount of interest from sources in country $X$ that is received by a nonresident of country $X$. Country $X$ law imposes the

\footnotetext{
${ }^{4}$ For example, see International Business Machine Corp. v. United States, 38 Fed. Cl. 661, 675 (1997); Schering Corp v. Commissioner, 69 T.C. 579, 600-603 (1978); Coca-Cola Co. v. Commissioner, 149 T.C. No. 21, at 15-16 (2017).

${ }^{5}$ Procter \& Gamble Co. v. United States, 2010-2 U.S.T.C. ๆ 50,593, at 85,545 (S.D. Ohio 2010)
} 
tax on the nonresident recipient and requires any resident of country $X$ that pays such interest to a nonresident to withhold and pay over to country $X 25$ percent of such interest, which is applied to offset the recipient's liability for the 25 percent tax. A tax treaty between the United States and country $X$ overrides internal law of country $X$ and provides that country $X$ may not tax interest received by a resident of the United States from a resident of country $X$ at a rate in excess of 10 percent of the gross amount of such interest. A resident of the United States may claim the benefit of the treaty only by applying for a refund of the excess withheld amount (15 percent of the gross amount of interest income) after the end of the taxable year. A, a resident of the United States, receives a gross amount of $100 u$ (units of country $X$ currency) of interest income from a resident of country $X$ from sources in country $X$ in the taxable year 1984, from which $25 \mathrm{u}$ of country $X$ tax is withheld. $A$ does not file a timely claim for refund. $15 \mathrm{u}$ of the amount withheld $(25 \mathrm{u}-10 \mathrm{u})$ is not a compulsory payment and hence is not an amount of tax.

On its face, this is a justified application of the noncompulsory payment rule, because the taxpayer could under the specified facts easily obtain a refund of the extra $15 \mathrm{u}$ by filing a refund claim. It is unclear whether any actual taxpayer is ever so negligent. More commonly, the taxpayer faces a foreign withholding agent that ignores the treaty by applying the higher withholding amount, and the taxpayer's efforts to obtain a refund may be unavailing in many countries that follow the principle that a tax withheld can never be refunded.

But the example raises an interesting question: Suppose there was no treaty, what would the result have been? The answer is clearly that in that case there would be withholding of $25 \mathrm{u}$ with no refund and a full foreign tax credit. So here we have a situation in which the tax treaty by its very existence and by the terms of the relevant article raises the US taxpayer's US tax liability because it now has to pay $25 \mathrm{u}$ to $\mathrm{X}$ and another $15 \mathrm{u}$ to the United States. What about the ability of the US taxpayer to choose not to invoke the treaty if this leads to a more favorable tax result? ${ }^{6}$

In my opinion, such a result is unconstitutional because the tax treaty raises the US taxpayer's US tax, in violation of the Origination Clause. ${ }^{7}$

More broadly, one may question the policy rationale behind the noncompulsory payment rule, which as far as I know is unique among countries that allow foreign tax credits, just as the fact that US tax treaties are self-executing puts the US in a small minority of countries that do not require any legislation for a tax treaty to come into effect. ${ }^{8}$ The noncompulsory payments rule is full of limitations that are difficult for taxpayers to navigate: When is "the cost thereof (including the risk of offsetting or additional tax liability) ... reasonable in light of the amount at issue and the likelihood of success"? The answer to that may be difficult for a

\footnotetext{
${ }^{6}$ In general, taxpayers may choose between the Code and the treaty, as long as they are consistent. See, e.g., Rev. Rul. 84-17, 1984-1 C.B. 308; Rev. Rul. 80-147, 1980-1 C.B. 16.

${ }^{7}$ Kysar argues that based on the case law a treaty can be considered as falling under the Origination Clause even if it just changes the tax result, not just if it raises more revenue, but in this case the treaty actually raises more revenue. Kysar, supra.

${ }^{8}$ Kysar, supra.
} 
taxpayer to ascertain. And how does a taxpayer distinguish transactions that fall under the rule from transactions that "alter its form of doing business, its business conduct, or the form of any business transaction"? Moreover, the IRS has lost most of the cases it litigated under the rule.

Perhaps it is time to eliminate the noncompulsory payment rule as too complex and not worth the effort it requires from both taxpayers and the IRS, as well as sometimes unconstitutional. In addition, the rule could be challenged if the Supreme Court does away with Chevron deference because it has no basis in the statutory text. If that outcome is considered too generous to taxpayers who would be tempted to be negligent at the expense of the fisc, the solution may be to place limits on full creditability, as Dan Shaviro has long advocated and as Congress has done for GILTI. ${ }^{9}$

\footnotetext{
${ }^{9}$ See Shaviro, Daniel, The Case Against Foreign Tax Credits (March 2010). NYU School of Law, Public Law Research Paper No. 10-12, NYU Law and Economics Research Paper No. 10-09, Available at SSRN: https://ssrn.com/abstract=1547312 or http://dx.doi.org/10.2139/ssrn.1547312; IRC section 250 (imposing an $80 \%$ limit on foreign tax credits offsetting of US tax under GILTI).
} 